\title{
Spiritual Well-being, Parent Attachment, and Moral Disengagement among College Students
}

\author{
Hazhira Qudsyi, Fani Eka Nurtjahjo, Nyda Afsari, Hanifah Nur Fitriani, and Achmad Sholeh
}

\begin{abstract}
This study aims to analyze prediction of spiritual well-being and parent attachment to moral disengagement among college students in Indonesia and China. The hypothesis on this study that both spiritual well-being and parent attachment can predict moral disengagement among college students. This study was conducted with a quantitative approach and performed in Universitas Islam Indonesia, Yogyakarta, Indonesia and Zhejiang University, Hangzhou Province, China. Participants of this study were 100 college students. Measurement of moral disengagement was done by using Moral Disengagement Scale which developed by Bandura, spiritual well-being variable was measured using The Spiritual Well-Being Scale (SWBS) by Darvyri et al, and parent attachment variable was measured using Inventory of Parent and Peer Attachment (IPPA) by Armsden and Greenberg. Result of data analysis showed that both spiritual well-being and parent attachment can predict moral disengagement among college students in level of significance $<0.01(R=0.394$, $p=0.001$ ), with an effective contribution of $\mathbf{1 5 . 5}$ percent. There are significant correlation between spiritual well-being, parent attachment, and moral disengagement among college students in Indonesia and China. Besides that, result of data analysis showed that the highest effective contribution on moral disengagement was from mother attachment variable, with an effective contribution of 12.67 percent, and the lowest predictor was from spiritual well-being variable, with an effective contribution of 0.07 percent. Mother attachment is the highest predictor, even the other variables not included into measurement, mother attachment can predict moral disengagement independently. Weakness and research implications will be discussed in this paper.
\end{abstract}

Index Terms-Moral disengagement, spiritual well-being, parent attachment.

\section{INTRODUCTION}

Moral development becomes one of important dimensions in individual socio-emotional development. Moral development is closely related to rules and conventions about what individuals should do in their interactions with others [1]. According to Hoffman, morality includes a feeling, which includes empathy and guilt. In addition, morality also includes a reasoning, which includes ability to understand the rules, distinguish right and wrong, and take perspective from others [2]. In line with what was stated by Berndt [3], that morality includes more than just thinking, where morality includes a behavior. Not only that, moral is like a good thing in accordance with social norms [4].

Manuscript received December 29, 2017; revised March 12, 2018.

Hazhira Qudsyi and Fani Eka Nurtjahjo are with Department of Psychology Faculty of Psychology and Socio-Cultural Sciences Universitas Islam Indonesia, Indonesia (hazhira.qudsyi@uii.ac.id).

Nyda Afsari, Hanifah Nur Fitriani, and Achmad Sholeh are students in Department Psychology Faculty of Psychology and Socio-Cultural Sciences Universitas Islam Indonesia, Indonesia.
One of concepts in moral studies is related to moral disengagement. Bandura basically developed the concept of moral disengagement as a part of social cognitive theory. The theory offers a perspective of human behavior which the control of human behavior beyond the mind and behavior itself through a process of self-regulation. According to Bandura, moral disengagement includes three mechanisms which is displacement of responsibility, diffusion of responsibility, and distortion of consequences. Bandura stated that moral disengagement can explain how normal people can engage on unethical behavior without any feelings of regret or self-blame [5].

Arsenio and Lemerise think that moral behavior can be the key to emergence of misbehavior and aggressive behavior. Bandura stated that moral disengagement has been linked to aggressive and antisocial behavior in children and adults. Turner in his research mentions that moral disengagement associated with bullying and aggressive behavior and negatively correlated with prosocial behavior. It was also found that men have higher scores than women in moral disengagement behavior, excessive aggression, and bullying [6]. Barsky et al in their research stated that moral disengagement in the form of moral justification as well as tossing of responsibility significantly related to unethical behavior. Moral justification is the most powerful predictor of unethical behavior [7]. In fact, there are still many behaviors that arise among people that indicate moral disengagement behavior, such as aggressive behavior, bullying, criminal behavior, delinquency, and other forms of cheating behavior (e.g., academic dishonesty, unethical business behavior, etc.).

Moral disengagement behavior is influenced by many things. Basically, factors that affect moral disengagement are by internal factors and external factors. These internal factors include personality factors [8]-[11] motivation [8], [9], gender [11]-[14], trait and moral identity (including internalization and symbolization, empathy) [13], spirituality, mood, age [14], and moral judgment [15]. Some external factors considered to influence moral disengagement are attachment [16], school climate and culture, social relation, academic success, ethnicity, family system [14], time of the day [17], religion [18], organization climate [11].

Based on previous research, it can be seen that spirituality and attachment can be factors that influence moral disengagement behavior among people. This study focuses more on the role of spiritual well-being and parent attachment to moral disengagement of people. In this case, there are relationship between spiritual well-being, parent attachment, and moral disengagement among college students? Are spiritual well-being and parent attachment can predict moral disengagement among college students? 


\section{RESEARCH METHOD}

\section{A. Participants}

Participants of this study were 50 college students from Universitas Islam Indonesia, Yogyakarta, Indonesia, and 50 college students from Zhejiang University, Hangzhou, China.

\section{B. Measurement}

This study was done by quantitative research to test empirically prediction of spiritual well-being and parent attachment to moral disengagement. And to collect the data, this study used self-report scale for three variables. Moral disengagement scale in this study was adapted from Moral Disengagement Scale by Detert [19]. This scale was developed by Bandura. Reliability coefficient of this scale was 0.87 (Cronbach Alpha Coefficient), with 32 items and divided into 8 subscales (moral justification, euphemistic labeling, advantageous comparison, displacement of responsibility, diffusion of responsibility, distortion of consequences, attribution of blame, and dehumanization). Spiritual well-being scale in this study was adapted from Spiritual Well-Being Scale by Darvyri et al [20]. Reliability coefficient of this scale was 0.882 (affiliation with God), 0.738 (satisfaction with life), and 0.669 (alienation from God-sense of meaningless life), with 20 items. Parent attachment in this study was measured with Inventory of Parent and Peer Attachment (IPPA), that was adapted from Armsden and Greenberg [21]. Reliability coefficient of this scale was 0.93 , with part of mother attachment was 0.87 and father attachment was 0.89. IPPA has 25 items and divided into 3 subscales (trust, communication, and alienation).

\section{Data analysis}

This study used regression analysis to analyze prediction of spiritual well-being and parent attachment to moral disengagement. This analysis method also used to predict each variable to moral disengagement.

\section{RESULTS AND DISCUSSION}

This study is intended to test empirically predictions of spiritual well-being and parent attachment to moral disengagement in college students. Based on data which have normal distribution, linearity, and multicolinearity, so to test hypothesis of this study, we used regression analysis. Regression analysis result can be seen in table below.

TABLE I: RESULT OF REGRESSION ANALYSIS

\begin{tabular}{lcccc}
\hline \multicolumn{1}{c}{ Research Variables } & F & p & R & $\mathbf{R}^{2}$ \\
\hline $\begin{array}{l}\text { Mother Attachment*, } \\
\text { Father Attachment, }\end{array}$ & 5.870 & 0.001 & 0.394 & 0.155 \\
Spiritual Well-being - & & & & \\
Moral Disengagement & & & & \\
*parent attachment = mother attachment and father attachment &
\end{tabular}

Based on analysis, results showed a very significant correlation between spiritual well-being, parent attachment (mother attachment and father attachment), and moral disengagement among college students in Indonesia and China. This result was obtained from value of $r=0.394$ and $p$ $=0.001(p<0.01)$. Thus, it can be said that spiritual well-being, mother attachment, and father attachment together can predict significantly moral disengagement among college students in Indonesia and China, with effective contribution of 15.5 percent.

TABLE II: RESULT OF REGRESSION ANALYSIS (PREDICTOR OF EACH INDEPENDET VARIABLES)

\begin{tabular}{lcccc}
\hline $\begin{array}{l}\text { Predictors of } \text { moral } \\
\text { disengagement }\end{array}$ & $\mathbf{F}$ & $\mathbf{p}$ & $\mathbf{R}$ & $\mathbf{R}^{2}$ \\
\hline $\begin{array}{l}\text { Mother Attachment, } \\
\text { Father Attachment }-\end{array}$ & 8.895 & 0.000 & 0.394 & 0.155 \\
$\begin{array}{l}\text { Moral } \\
\text { Disengagement }\end{array}$ & & & & \\
$\begin{array}{l}\text { Mother Attachment - } \\
\text { Moral } \\
\text { Disengagement }\end{array}$ & 17.048 & 0.000 & 0.385 & 0.148 \\
\hline
\end{tabular}

Based on additional analysis conducted, there was a very significant relationship between mother attachment and father attachment to moral disengagement among college students, when the influence of spiritual well-being was controlled. This result was obtained from value of $r=0.394$ and $p=0.000(p<0.01)$. Based on these results, it can be argued that parent attachment can predict significantly moral disengagement in college students, with effective contribution of 15.5 percent. These results indicate that parent attachment becomes a variable that can independently predict moral disengagement in college student, without look at the influence of spiritual well-being variable. Based on data analysis, spiritual well-being variables can not predict moral disengagement in college students if not considering the effect of parent attachment variable. It can be argued that, spiritual well-being variable can not be an independent variable to predict moral disengagement in college students, and should be together with parent attachment variable if it is to be a predictor of moral disengagement in college students.

Based on additional analysis, results obtained that mother attachment variable becomes a variable that has the largest contribution in predicting moral disengagement. This result is obtained from $\mathrm{r}=0.385$ and $\mathrm{p}=0.000$ ( $\mathrm{p}<0.01$ ), with effective contribution of 14.8 percent. Based on analysis, it can be said that mother attachment variable becomes the most powerful variable in predicting moral disengagement among college students. Although other variables (in this case father attachment and spiritual well-being) are not included in data analysis, mother attachment can predict moral disengagement independently.

This study showed consistent results with previous studies, where this study can prove that spiritual well-being and parent attachment are closely correlated to moral disengagement [22]-[27]. In particular, with regard to attachment between parent and child, Chugh et al. [28] describes that individuals with secure attachment tend to be more able to refrain from moral disengagement behavior. Looking at the context of parents as part of family system, this study was also consistent with previous research findings that explain the role of families in moral development in children [4], [29].

Al-Istanbuli [30] says that there is still a lot of moral decadence happening today because it impact from the destruction of education, both at school and at home, where the family is also responsible for children's education. In line with previous opinions, Daradjat [3] suggests that moral will grow and evolve from the experiences that children have 
been through since the child was born. Here the role of parents in moral education among children in everyday life is very important. Fajarwati [3] added that one way for a child to gain an understanding of moral concept is first from their parents.

More specifically, this study showed that in context of parent attachment, mother attachment has an enormous role in the emergence of moral disengagement behavior in children, even if the child has entered adolescence and early adulthood. This is understandable considering the culture of caring that takes place both in Indonesia and in China is still dominated by mother figure. As stated by Mulder [31], there is a difference in behavior between father and mother in parenting to their children. In Eastern tradition, father has a position as head of family in charge of controlling the course of family rules. Father has authority to make family decisions even if opinions from mothers and children are taken into account. Mothers play a greater role in ensuring their children are in good health, both physically and psychologically, and meeting needs of their children. Children in Eastern cultures also have greater physical closeness to parents (especially mothers) than children in Western cultures. When they were little, they often saw her mother's arms, both during sleep and during meals. Mothers in Eastern cultures also keep their children while working on housework or while shopping at the market, because mothers can not leave their children at home [31].

Mother attachment is also shown through the results of Hakim et al research [31], that the most feelings felt by college students when interacting with mother are comfortable, compassion, happiness, and the feeling of having to repay what has been given (indebtedness). Unlike the case with college student feelings when interacting with father, where the most widely felt first is the feeling of having to repay what has been given (indebtedness). With regard to the context, it is understandable why mother attachment has the greatest contribution to moral disengagement.

This research also analyzes each group respondents, Indonesian students and Chinese students.

TABLE III. RESULT OF REGRESSION ANALYSIS (INDONESIAN STUDENTS)

\begin{tabular}{lcccc}
\hline \multicolumn{1}{c}{ Research Variables } & F & $\mathbf{p}$ & $\mathbf{R}$ & $\mathbf{R}^{2}$ \\
\hline $\begin{array}{l}\text { Mother Attachment, } \\
\text { Father Attachment, }\end{array}$ & 7.082 & 0.001 & 0.562 & 0.316 \\
$\begin{array}{l}\text { Spiritual Well-being } \\
\text { Moral Disengagement }\end{array}$ & & & & \\
$\begin{array}{l}\text { Mother Attachment, } \\
\text { Father Attachment }\end{array}$ & 10.612 & 0.000 & 0.558 & 0.311 \\
$\begin{array}{l}\text { Moral Disengagement } \\
\text { Mother Attachment }\end{array}$ & & & & \\
Moral Disengagement & 20.816 & 0.000 & 0.550 & 0.302 \\
\hline
\end{tabular}

Based on additional analysis, results obtained that there were significant correlation between mother attachment, father attachment, spiritual well-being, and moral disengagement among Indonesian college student. Moral disengagement can predict significantly from mother attachment, father attachment, and spiritual well-being together, with effective contribution of all variables to moral disengagement are 31.6 percent. On Indonesian students, highest effective contribution to moral disengagement is from mother attachment (30.2 percent), and the lowest effective contribution is from father attachment $(2.96 \%)$. From this result, it can be stated that mother attachment is the highest contribution to moral disengagement, even the other variables not included into measurement, mother attachment can predict moral disengagement among Indonesian students independently. On the other hand, spiritual well-being can not predict moral disengagement independently, and this variable can predict moral disengagement among students if combine with parent attachment.

\begin{tabular}{lcccc}
\multicolumn{5}{c}{ TABLE IV: RESULT OF REGRESSION ANALYSIS (CHINESE STUDENTS) } \\
\hline \multicolumn{1}{c}{ Research Variables } & F & p & R & $\mathbf{R}^{2}$ \\
\hline $\begin{array}{l}\text { Mother Attachment, } \\
\text { Father Attachment, }\end{array}$ & 1.843 & 0.153 & 0.328 & - \\
$\begin{array}{l}\text { Spiritual Well-being } \\
\text { Moral Disengagement }\end{array}$ & & & & \\
$\begin{array}{l}\text { Mother Attachment, } \\
\text { Spiritual Well-being }\end{array}$ & 2.714 & 0.077 & 0.322 & - \\
$\begin{array}{l}\text { Moral Disengagement } \\
\text { Mother Attachment }\end{array}$ & & & & \\
Moral Disengagement & 4.700 & 0.035 & 0.299 & 0.089 \\
\hline
\end{tabular}

Based on analysis among Chinese students, there were no correlation between mother attachment, father attachment, spiritual well-being, and moral disengagement among Chinese college students. From this result, moral disengagement can not predict form mother attachment, father attachment, and spiritual well-being together. But, there were significant correlation between mother attachment and moral disengagement among college students from China, with an effective contribution of mother attachment to moral disengagement is 8.9 percent.

From the additional analysis between Indonesian students and Chinese students, we found interesting things, there were differences results between groups. On Indonesian students, spiritual well-being can predict moral disengagement, although this variable only can predict together with other variables, which in this research are parent attachment (mother attachment and father attachment). On the other hand, spiritual well-being can not predict moral disengagement among Chinese students at all. The only one variable that can predict moral disengagement among Chinese students is only mother attachment, but with low effective contribution.

This result support previous researches, that spiritual (and also religiosity) correlate and have an impact to moral behavior among Indonesia people. Spiritual being one of variable that can have correlation with moral behavior, such as cheating behavior (fraud) [34], morality [35], sexual activity [36], and corruption intentions [37]. Values in Indonesia put religion (faith of God) into National principle and guidelines for Indonesian society. That is one of the reason why spirituality and religiosity being variables which has a significant role in the life of Indonesian society.

On the other hand, this research showed that spirituality (spiritual well-being) has no impact to moral behavior among Chinese students. Lou stated that Chinese spirituality has not yet been systematically studied, not only is there a lack of theoretical discussion of its conceptualization, but underlying mechanism has not been studied or developed [38]. Researches realize that we're hard to find research about spirituality, especially about spiritual well-being, among Chinese society. When researchers discussed directly with 
Chinese students, they said that Chinese people not performing certain worship (religion) rituals. Chinese people assumed that, at every activity in their life, have nothing to do with spirituality. Also, they not really understand about what is spirituality. In line with Lou, that it is more desirable to define spiritual well-being by focusing on the concepts of the meaning of life or life energy [38]. Maybe for this reason, spiritual well-being have no correlation with moral disengagement among Chinese students.

\section{CONCLUSION}

Based on previous analysis and discussion, it can be concluded that spiritual well-being and parent attachment together can predict significantly moral disengagement on college students. Another conclusion from this research is that parent attachment (especially mother attachment) has a predictive power independently to moral disengagement when compared with spiritual well-being variable.

\section{REFERENCES}

[1] J. W. Santrock, "Life-span development: Perkembangan masa hidup," Edisi Kelima ed., Jakarta: Penerbit Erlangga, 2002.

[2] R. M. Berns, "Child, family, school, community: Socialization and support," Thomson Learning Inc, 2004.

[3] H. Qudsyi, "Hubungan antara keberfungsian keluarga dengan penalaran moral pada anak usia akhir (late childhood)," Yogyakarta, 2007.

[4] S. Syahira and H. Qudsyi, "Hubungan antara keberfungsian keluarga dan penalaran moral pada remaja awal," Yogyakarta, 2015.

[5] J. Detert, "Moral disengagement in ethical decision making: A study of antecedents and outcomes," Journal of Applied Psychology, vol. 93, no. 2, pp. 374-391, 2008.

[6] R. Turner, "Moral disengagement as a predictor of bullying and aggression: Are there gender differences?," USA, 2008.

[7] A. Barsky, G. Islam, M. Zyphur and E. Johnson, "Investigating the effects of moral disengagement and participation on unethical work behavior," EnANPAD, vol. 23, no. 27, pp. 1-17, 2006.

[8] S. Vollum, J. Buffington-Vollum, and D. Longmire, "Moral disengagement and attitudes about violence towards animals," Society \& Animals, vol. 12, no. 3, pp. 209-235, 2004.

[9] K. Dhingra, A. Debowska, K. Sharratt, P. Hyland, and S. Kola-Palmer, "Psychopathy, gang membership, and moral disengagement among juvenile offenders," Journal of Criminal Psychology, vol. 5, no. 1, pp. 13-24, 2014.

[10] E. Sagone and M. Caroli, "Personality factors and civic moral disengagement in law and psychology university students," in Procedia Social and Behavioral Sciences, 3rd World Conference on Learning, Teaching, and Educational Leadership, 2012.

[11] I. Saidon, J. Galbreath, and A. Whiteley, "Antecedents of moral disengagement: Preliminary empirical study in Malaysia," in Proc. 24th Annual Australian and New Zealand Academy of Management Conference, B. Gurd, Ed., Adelaide, Australian and New Zealand Academy of Management (ANZAM), 2010.

[12] S. Cory and A. Hernandez, "Moral disengagement in business and humanities major: An explanatory study," Research in Higher Education Journal, vol. 23, pp. 1-11, 2014.

[13] Z. Aprilia and Solicha, "Faktor-faktor yang mempengaruhi moral disengagement remaja," TAZKIYA Journal of Psychology, vol. 18, no. 1 , pp. 1-18, 2013.

[14] R. George, "Moral disengagement: An explanatory study of predictive factors for digital aggression and cyberbullying," USA, 2014.

[15] G. McCreary, "The impact of moral judgment and moral disengagement on hazhing attitudes and bystander behavior in college males," USA, 2012.

[16] D. Chugh, M. Kern, Z. Zhu, and S. Lee, "Withstanding moral disengagement: Attachment security as an ethical intervention," Journal of Experimental Social Psychology, vol. 51, no. 1, pp. 88-93, 2014.

[17] M. Kouchaki and I. Smith, "The morning morality effect: The influence of time of day on unethical behavior," Psychological Science Online First, 2013.
[18] H. Marquette, "'Finding god' or 'moral disengagement' in the flight against corruption in developing countries? Evidence from India and Nigeria," Public Admin Dev, 2011.

[19] J. Detert, "Moral disengagement in ethical decision making: A study of antecedents and outcomes," Journal of Applied Psychology, vol. 93, no. 2, pp. 374-391, 2008.

[20] P. Darvyri, M. Galanakis, A. Avgoustidis, S. Vasdekis, A. Artemiadis, X. Tigani, G. Chrousos, and C. Darvyri, "The spiritual well-being scale (SWBS) in Greek population of Attica," Journal of Criminal Psychology, vol. 5, pp. 1575-1582, 2014.

[21] G. Armsden and M. Greenberg, "Inventory of parent and peer attachment," 2009

[22] F. Wijayati and W. Pramesti, "How spiritual value and spiritual wellbeing form Islamic perspective as an alternative of agency problem," Journal of Education and Social Sciences, vol. 4, pp. 107-117, 2016.

[23] M. Fernando and R. Chowdhury, "The relationship between spiritual well-being and ethical orientations in decision making: An empirical study with business executives in Australia," Journal of Business Ethics, vol. 95, no. 2, pp. 211-225, 2010.

[24] P. McGhee and P. Grant, "Spirituality and ethical behaviour in the workplace: Wishful thinking or authentic reality," EJBO Electroninc Journal of Business Ethics and Organization Studies, vol. 13, no. 2, pp. 61-69, 2008

[25] M. Ijzendoorn, "Attachment, emergent morality, and aggression: Toward a developmental socioemotional model of antisocial behaviour," International Journal of Behavioral Development, vol. 21 no. 4, pp. 703-727, 1997

[26] D. Stephens, "A correlational study on parental attachment and moral judgment competence of millennial generation college students," 2009.

[27] Z. Bao, W. Zhang, X. Lai, W. Sun and Y. Wang, "Parental attachmen and Chinese adolescents' delinquency: The mediating role of mora disengagement," Journal of Adolescence, vol. 44, pp. 37-47, 2015.

[28] D. Chugh, M. Kern, Z. Zhu and S. Lee, "Withstanding moral disengagement: Attachment security as an ethical intervention," Journal of Experimental Social Psychology, vol. 51, no. 1, pp. 88-93, 2014.

[29] H. Qudsyi and U. Gusniarti, "Hubungan antara keberfungsian keluarga dengan penalaran moral pada anak usia akhir," Indigenous Jurnal Ilmiah Berkala Psikologi, vol. 9, no. 1, pp. 44-61, 2007.

[30] M. Al-Istanbuli, Parenting guide: Dialog imajiner tentang cara mendidik anak berdasarkan Alquran, as-sunnah, dan psikologi, Jakarta: Hikmah PT Mizan Publika, 2006.

[31] M. Hakim, Supriyadi and K. Yuniarti, "The contents of Indonesian child-parent attachment: Indigenous and cultural analysis," ISSBD Supplement to International Journal of Behavioral Development, vol. 62, no. 2, 2012.

[32] D. Stephens, "A correlational study on parental attachment and moral judgment competence of millennial generation college students," 2009.

[33] Z. Bao, W. Zhang, X. Lai, W. Sun and Y. Wang, "Parental attachment and Chinese adolescents' delinquency: The mediating roel of moral disengagement," Journal of Adolescence, vol. 44, pp. 37-47, 2015.

[34] I. D. Pamungkas, "Pengaruh religiusitas dan rasionalisasi dalam mencegah dan mendeteksi kecenderungan kecurangan akuntansi," $J$. Ekon. dan Bisnis, vol. 15, no. 2, pp. 48-59, 2014.

[35] I. F. Reza, "Hubungan antara religiusitas dengan moralitas pada remaja di Madrasah Aliyah (MA)," Humanitas (Monterey. N. L)., vol. 10, no. 2, pp. 45-58, 2013.

[36] D. L. Pradisukmawati and E. Darminto, "Hubungan antara tingkat religiusitas dengan tingkat aktivitas seksual pada remaja akhir," Psympathic J. Ilm. Psikol., vol. 1, no. 2, pp. 179-185, 2014.

[37] Z. I. Wahyuni, Y. Adriani, and Z. Nihayah, "The relationship between religious orientation, moral integrity, personality, organizational climate and anti corruption intentions in Indonesia," Int. J. Soc. Sci. Humanit., vol. 5, no. 10, pp. 860-864, 2015.

[38] V. W. Q. Lou, Spiritual WellBeing of Chinese Older Adults. Conceptualization, Measurement and Intervention. SpringerBriefs in Well-Being and Quality of Life Research, 2015.

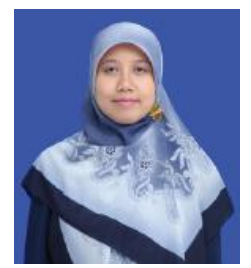

Hazhira Qudsyi is a lecturer at Department of Psychology, Faculty of Psychology and Socio-Cultural Sciences, Universitas Islam Indonesia. She studied master of psychology Science with speciality in educational psychology. Her research interests are in well-being, positive psychology at school, support system context in students education, moral, peer counselling, and cognitive psychology. She also becomes head 
division of student affair and head divison of student counselling center in Universitas Islam Indonesia.

Fani Eka Nurtjahjo is a lecturer at Department of Psychology, Faculty of Psychology and Socio-Cultural Sciences, Universitas Islam Indonesia. She studied professional master of professional psychologist with speciality in educational psychology. Her research interests are in cognitive psychology, learning.

Nyda Afsari, Hanifah Nur Fitriani, and Achmad Sholeh are undergraduate students at Department of Psychology, Faculty of Psychology and Socio-Cultural Sciences, Universitas Islam Indonesia. 